\title{
Ten-Year-Old Mummified Corpse Found in Domestic Setting in Rotterdam the Netherlands
}

Karen Eline van den Hondel ${ }^{1^{*}}$, Marcel Buster ${ }^{2}$, Peter Paul Bender ${ }^{2}$ and Udo Reijnders ${ }^{2}$

${ }^{1}$ Forensic Physicians Rotterdam Rijnmond (FARR), Rozenlaan, Rotterdam, The Netherlands

${ }^{2}$ Public Health Service, P.O. Box 2200, 1000 CE Amsterdam, The Netherlands

"Corresponding author: van den Hondel KE, Forensic Physicians Rotterdam Rijnmond (FARR), Rozenlann 115, 3051 LP Rotterdam, The Netherlands, Tel: +31(0)633840-850; E-mail: vdhondel@farr.nl

Received date: May 30, 2016; Accepted date: July 09, 2016; Published date: July 15, 2016

Copyright: (c) 2016 van den Hondel KE, et al. This is an open-access article distributed under the terms of the Creative Commons Attribution License, which permits unrestricted use, distribution, and reproduction in any medium, provided the original author and source are credited.

\begin{abstract}
Introduction: On November 21, 2013 an approximately ten-year-old mummified corpse of a 74-year-old female was found in the living room of her apartment located near the city-center of Rotterdam, the Netherlands.

Definition: A domestic-setting corpse is defined as a dead body found in an urban area with a minimum postmortem interval of 24 hours.

Discussion: Not much research is performed about domestic setting corpses. In Rotterdam were 145 cases with a postmortem interval of at least 14 days in the period January 2006 until November 21, 2013. In the period from the finding of the ten-year-old mummified corpse (November 21, 2013) until December 31, 2015 there have been 42 domestic setting corpses with a postmortem interval of at least 14 days found in Rotterdam.
\end{abstract}

Conclusion: We recommend doing an extensive study with a broad perspective to examine the demographic and medical/mental problems and the characteristics of domestic setting corpses so local governments can arrange specific measurements to decrease the number of domestic setting corpses and lower the number of days' people lie dead in their homes.

Keywords: Domestic setting corpse; Forensic physician; Mummified corpse; Forensic medicine

\section{Introduction}

After death decomposition of a body will start. Mummification is usually as of long-term (between 6-12 months) change after death, a drying of the tissues instead of liquefying putrefaction. Like the other modes of decomposition, this can even be partial and can coexist with them in different areas of the same body.

There are cases described where mummification occurred in a much shorter time period. This is called precocious mummification what occurs in extreme confined environment, or with particular microclimate conditions [1].

\section{Case Report}

On November 21, 2013 an approximately ten-year-old mummified corpse of a 74-year-old female was found in the living room of her apartment located near the city-center of Rotterdam, the Netherlands.

Maintenance work of the street in front of the apartment forced the street workers to come in contact of the residents. When they saw a pile of mail behind the door, they contacted the police to open the apartment where the body was found.

In the Netherlands either general practitioners as well as forensic physicians do the external examination when a dead body is discovered. When the place or date of death is unknown the forensic physician is usually called to do the external examination. The Dutch law also requires police papers for the funeral when time of death is unknown. These deaths usually have a post mortem interval of at least 24 hours.

The body was well preserved through the mummification process and no external injuries were observed. The presumed season of death was autumn/winter which may very well explain the rapid skin dehydration, since the heating was not turned on.

On the body and around there were signs of former insect activity present, mainly dead flies, maggots and pupa (cocoons) lying on the body and in the (environment of the) corps/putrefactive fluids.

The body was lying on her back on the linoleum in front of the couch with her head on a pillow. Next to her was a pillow from a chair. She was completely naked and partly covered with a blanket on her left thigh. Her feet were covered with a towel and plastic canvas. The towel and the blanket were fastened with a safety-pin.

The corpse was light in weight, fixed in the stretched out position by the brittle dehydrated tissues.

The linoleum on which the body was lying and the pillow on which the head was lying were covered of the early putrefactive fluids coming from the corpse. The skin was dried and felt and looked like leather.

Time of death could be estimated on a combination of observations in the home. The presumed occupant of the apartment wrote dates on mail she opened. A paper television-guide in black-and-white lied open on a table showing a specific week. Different television programs 
were marked. The mail on the bottom of the doormat was checked for the date. We could conclude that the woman died in the winter of 2003.

The manner of death was undetermined but presumed natural. Based on the ante-mortem data available the corpse was identified by DNA research. Professionals from the Netherlands Forensic Institute collected muscle tissue and bone from the thigh. The muscle was well preserved and recognizable as reddish skeletal muscle. DNA was collected from this tissue and was used to determine a family ancestor's relationship with her presumable daughter. The daughter did not have contact with her mother due to negative events in the past. In the Netherlands the family decides whether or not an autopsy with toxicology is performed, if the manner of death is concluded to be natural. In this case the family decided they did not want any further investigation of the body.

This case showed that authorization of automatic payments of rent and public services has specific disadvantages.

Recently CNN reported the story of a schoolboy who was exploring an abandoned house in the US state of Ohio, when discovering a fiveyear-old mummified corpse of a man inside a closet [2]. The coroner called this finding very unique. Last April a five-year-old mummified body of an elderly woman was pulled from the home of a San Francisco woman that neighbors described as a hoarder [3].

After the finding of the ten-year-old corpse the media was all over it in the Netherlands. Questions that came to mind were: how is this possible? And concerns were expressed: are these people lonely? Do we need to take better care or notice to the older population? Review of the literature made clear little research is performed on this topic.

\section{Definition}

The phenomenon of a finding of a corpse in a house is not new. Several studies investigated this issue. In Germany these corpses are called "wohnungsleiche" and in the international literature they are called domestic-setting corpse [4]. There is no agreement on the exact definition, but most studies describe a domestic-setting corpse as a dead body found in an urban area with a minimum postmortem interval of 24 hours. Different studies came with the following characteristic; most domestic-setting corpses were male, died at an age below the average life expectancies, psychiatric diseases present, living alone, limited to no social relationships or contacts [4-6].

\section{Discussion}

After the discovery of the ten-year-old mummified corpse in Rotterdam, the local authorities of Rotterdam financed several measures to decrease the number domestic setting corpses (145 cases with a postmortem interval of at least 14 days in the period January 2006 until November 21, 2013) and especially the number of persons lying dead in their home for a longer period of time [7].

A program labeled "voor mekaar" (Dutch for: take care of each other) was produced to prevent isolation. As a part of this program the local authorities have labeled risk groups in Rotterdam. The key is to identify and contact the isolated people. The first risk group contains people above 65 years living alone. The local authorities will focus on twenty-one neighborhoods with a high percentage of this risk group, but will be unrolled through the whole city of Rotterdam. A social network will be formed with participation of local organizations in three categories: district counsels (for example the people who lost their spouse), local health case (for example the people who do not collect their medication anymore at the local pharmacy) and social services (for example the people who do not pay taxes anymore or with debts). Local organizations in the social network can easily report a case when there has not been contact for a while and if there are worries. The local network stimulates the organization to try to reach contact themselves. When the report is identified as a high risk, a local team pays a home visit to see if somebody is in need or still alive. The local authorities of Rotterdam also launched campaigns to get notoriety of the problem of isolated people to gain a feeling of solidarity; so people pay attention to their neighbors and report if they have not seen their neighbors for some time.

Another important risk group is people who refuse (mental) health care or have problems with alcohol or drugs. Nuisance reports with the police or local authorities can be delegated to local (mental) health care teams in the different district teams. Problematic is identification of the isolated people with (mental) health care problems who do not cause nuisance or are not in contact with any organization; the local social network hopefully identifies those people.

In the period from the finding of the ten-year-old mummified corpse (November 21, 2013) until December 31, 2015 there have been 42 domestic setting corpses with a postmortem interval of at least 14 days found in Rotterdam; this means in the two years after the finding of the mummy this is 21 a year. In the period before the finding of the mummy on average 18 cases a year were found. Two years of data is too soon to draw conclusions. Maybe this little rise could mean that the attention drawn from the finding of the mummy and the measurements have an effect, or just prove the opposite? It would be interesting to investigate in a few years if the number of days a person lies dead in their home is changing.

To actually decrease the number of domestic setting corpses or the days a person lies dead in their home the researchers suggest to do a broad study and analyze the domestic settings corpses in a broad epidemiologic perspective. When more characteristics are known about the influence of mental health problems/care, addiction, specific measurements could be arranged by the local government. In 2011 a study was conducted about domestic setting corpses. They concluded that domestic settings corpses are a problem of the big city [8]. Reasons they describe are a higher number of one person households and different building styles between the city and countryside. A study in 2002 described these people to be socially isolated [9].

Because a lot of the domestic settings corpses evaluated in this study did not have mental health care, domestic setting corpses could be seen as a measurement of the functioning of the public psychological health care. Further studies could focus on whether the domestic settings corpses are known with (mental) health care or that these people avoided any psychological help. In the last case, specific measurement could be arranged. Research described that especially males are less likely to perform help-seeking behavior compared to females [10]. In our cases (after the finding of the mummy) $86 \%$ was male and $45 \%$ of the cases there was a history of (avoidance of) mental health care and substance abuse.

When the ten-year-old body was found a lot of people in the Netherlands were shocked. The idea that someone could lie dead in their home for a long time made people sad and raised questions; how often does this happen, are these people lonely? Still little is known about questions raised in the study in 2011 about domestic settings corpses. Therefore, we recommend doing an extensive study with a 
Citation: van den Hondel KE, Buster M, Bender PP, Reijnders U (2016) Ten-Year-Old Mummified Corpse Found in Domestic Setting in Rotterdam the Netherlands. J Forensic Res 7: 330. doi:10.4172/2157-7145.1000330

Page 3 of 3

broad perspective to examine the demographic and medical/mental problems and the characteristics of domestic setting corpses so local governments can arrange specific measurements to decrease the number of domestic setting corpses and lower the number of days' people lie dead in their homes.

\section{References}

1. Marella GL, Perfetti E, Manciocchi S, Arcudi G (2013) A case of "precocious" mummification. J Forensic Leg Med 20: 122-124.

2. Gander K (2014) Schoolboy finds mummified body while exploring abandoned house.

3. Silverstein J (2015) Mummified body of elderly woman found in filthy San Francisco home, years after her death.

4. Merz M, Heidorn F, Birngruber CG, Ramsthaler F, Risse M, et al. (2012) Definition of a "domestic-setting corpse"--a retrospective study of 211 discoveries. Arch Kriminol 230: 115-127.
5. Merz M, Birngruber CG, Heidorn F, Ramsthaler F, Risse M, et al. (2011) Criteria for the classification as a "domestic-setting corpse"--a literature search and review to define the term. Arch Kriminol 228: 191-202.

6. Campobasso CP, Falamingo R, Grattagliano I, Vinci F (2009) The Mummified Corpse in a Domestic Setting. Am J Forensic Med Pathol 30: 307-310.

7. Gemeente (local authoritiy of) Rotterdam "Voor mekaar" (Dutch) (2014) Program to fight loneliness.

8. Smith E, Larsen DF, Rosdahl N (2011) To die alone, a big city problem? Ugeskr Laeger 163: 3069-3073.

9. Hönigschnabl S, Schaden E, Stichenwirth M, Schneider B, Klupp N, et al. (2002) Discovery of decomposed and mummified corpses in the domestic setting; a marker of social isolation? J Forensic Sci 47: 837-842.

10. Galdas PM, Cheater F, Marshall P (2005) Men and health help-seeking behavior: literature review. J Adv Nurs 49: 616-623. 